\title{
Quality characteristics of soft morning roll bread with different ratios of high yield tongil-type rice flours
}

\author{
Eun-Yeong Sim ${ }^{1}$, Hye-Young Park ${ }^{1}$, Ji Yoon Lee ${ }^{2}$, Jieun Kwak ${ }^{1}$, Jin-Young Lee ${ }^{1}$, \\ Yong-hee Jeon ${ }^{1}$, Choon-Ki Lee ${ }^{1}$, Ha-Cheol Hong ${ }^{3}$, Induck Choi ${ }^{1 *}$ \\ ${ }^{1}$ Post-Harvest Technology Division, National Institute of Crop Science, RDA, Suwon 16613, Korea \\ ${ }^{2}$ Paddy Crop Research Division, National Institute of Crop Science, RDA, Milyang 50424, Korea \\ ${ }^{3}$ Fuctional Food \& Nutrition Division, Department of Agro-food Resources, RDA, Iseo 55365, Korea
}

\section{다수성 통일형 쌀가루의 첨가 비율별 모닝빵의 품질특성}

\author{
심은영 ${ }^{1} \cdot$ 박혜영 $^{1} \cdot$ 이지윤 ${ }^{2} \cdot$ 곽지은 $^{1} \cdot$ 이진영 $^{1} \cdot$ 전용희 $^{1} \cdot$ 이춘기 $^{1} \cdot$ 홍하철 $^{3} \cdot$ 최인덕 $^{1 *}$ \\ 1농촌진흥청 국립식량과학원 수확후이용과, ${ }^{2}$ 농촌진흥청 국립식량과학원 논이용작물과, \\ 3농촌진흥청 국립농업과학원 기능성식품과
}

\begin{abstract}
In this study, we compared the quality characteristics of soft morning roll bread with different contents of two Korean high-yield tongil-type rice varieties, namely Hanareum4 and Keumkang1. The final and setback viscosities increased with increasing rice flour ratio as determined by a Rapid Visco Analyzer. The $\mathrm{pH}$ of the dough decreased as the rice flour ratio was decreased from $\mathbf{7 0} \%$ to $0 \%$, regardless of the rice cultivar, and the dough rose more when less rice flour was added. During the final fermentation stage, the volumes of the dough containing Keumkang1 were 32.2, 27.5, 23.0, and $21.0 \mathrm{~mL}$ when $0,30,50$, and $70 \%$ rice flour were added, respectively. The SEM images reveal that the dough forms a net-like morphology during fermentation, due to the decomposition of the wheat and rice flour. The volume and moisture contents of soft moming roll bread ranged in $90-192.5 \mathrm{~mL}$ and $38.25-40.06 \%$, respectively. The volume of the Keumkang1-containing bread loaf was higher than that of the Hanareum4-containing loaf. Texture profile analysis (TPA) results suggest that the hardness and chewiness of the bread containing $30 \%$ Keumkang1 is very similar to that of the $100 \%$-wheat bread regardless of rice varieties. The results suggest that Keumkang1 can replace wheat at a $\mathbf{3 0} \%$ level for morning roll bread purposes.
\end{abstract}

Key words : soft moming roll bread, dough, TPA, tongil-type rice flour, SEM

\section{서 론}

국민 1 인당 1 일 빵 섭취량은 $18.2 \mathrm{~g}(2012)$ 에서 20.9 $\mathrm{g}(2016)$ 으로 최근 5년간 $2.7 \mathrm{~g}(14.8 \%)$ 증가하여 1 인당 연간 90개(85 g기준) 빵을 섭취하는 것으로 나타났다(1). 빵은 조직감이 부드럽고 섭취가 간편하며 이동성이 좋은 장점이

*Corresponding author. E-mail : ichoi829@korea.kr Phone : 82-31-695-0605, Fax : 82-31-695-0609

Received 26 April 2019; Revised 13 June 2019; Accepted 30 August 2019.

Copyright (c) The Korean Society of Food Preservation. All rights reserved.
있어 아침밥 등 식사대용으로 소비하는 비율이 늘고 있다. 이에 따라 베이커리 업계에서는 빵에 건강 기능성 성분을 첨가한 간편식 웰빙 제품들을 선보이고 있다. 밀의 대부분 을 수입에 의존하고 있는 상황에서 수입밀의 일부를 쌀가루 로 대체할 수 있다면 식량자급률 향상에도 기여할 수 있다. 밀가루를 대체할 수 있는 쌀가루에 대한 관심이 증가하고 있고, 쌀가루를 이용한 베이커리 제품 연구가 활발히 진행 되고 있다. 우리나라는 2015년부터 쌀 관세화로 전환하면 서 쌀 소비를 확대하고 촉진할 수 있는 대안이 시급한 실정 이며, 쌀을 활용한 제과제빵 제품의 개발이 좋은 대안이 될 수 있을 것이다. 백미에는 약 $80 \%$ 전분과 6-7\%의 단백질, 그 외 지방, 섬유소가 소량 함유되어 있다. 현재, 식품가공 
산업에서의 쌀 소비량은 국내 쌀 생산량의 $10 \%$ 수준이다. 그 가운데 쌀가루 산업에 소비되는 쌀은 쌀 가공산업의 $12 \%$ 수준인 71 천 톤으로서 연 매출액은 774 억 원 정도이다 (2). 쌀가루의 원료 조달처로는 정부양곡이 59천 톤(83\%)이 고 시중구매가 12 천 톤(17\%)인데 시중구매 12 천 톤 중에서 일반 쌀이 6.3천 톤을 차지한다. 현재, 국내에서 개발된 쌀은 250 여 종이 넘는데, 그 중에서 다수성 쌀은 수량성이 높아 생산단가를 낮출 수 있으며, 한아름4호, 금강 1 호 등 17 가지 품종이 개발되어 보급되고 있다. 국내 쌀가루 시장 규모가 지속적으로 증가하고 있으며, 쌀가루 시장의 유망품목인 빵류의 소비 창출 및 증대 가능성에 대한 기대도 높아지고 있다. 그 동안 쌀빵에 대한 선행연구로는 쌀가루 습식처리 유무별 빵의 품질특성, 백미나 현미 첨가 비율별에 따른 특성차이, 일반 밥쌀용 품종으로 만든 빵의 품질특성 등의 내용이 다수를 차지하였다(3-5). 본 연구에서는 쌀 소비 확 대의 일환으로, 단위면적당 수량이 높은 2 개 품종을 건식쌀 가루로 제조하고, 쌀가루 첨가비율에 따라 모닝빵을 가공 하고 품질 특성에 미치는 영향을 평가하여 모닝빵에 적합한 원료 쌀 품종 선발 및 제품개발의 기초자료로 활용하고자 수행하였다.

\section{재료 및 방법}

\section{실험재료}

본 실험에서는 2017년 국립식량과학원에서 생산된 다수 성 통일형 벼인 한아름4호, 금강 1 호 2 품종을 시험재료로 선택하였다. 현미기(Model SY88-TH, Ssangyoung Ltd., Incheon, Korea)로 왕겨를 제거한 현미는 정미기(Model MC-250, Wakayama Co. Lt, Wakayama, Japan)를 이용하여 백미로 도정하였고 기류식 제분기(Air-Classification Mill, ACM185, Hankook Crusher Co., Incheon, Korea)로 제분하 여 150 mesh 체로 걸러 통과한 부분을 건식 쌀가루 시료로 사용하였다. 강력분(Samyangsa Corporation, Asan, Korea), 전지분유(Seoulmilk, Yangju, Korea), 소금(Haepyo, Seoul, Korea), 드라이이스트(Saf Instant, Lesaffre, Marcq-enBaroeul, France)는 마트에서 구입하여 사용하였다.

\section{반죽의 배합 및 제빵 방법}

모닝빵은 직접 반죽법(6)으로 가정용 반죽 혼합기 (CBM-H1000, Cuchen, Guangdong, China)를 이용하여 반죽 을 하였다. 금강 1 호와 한아름 4 호 쌀가루를 $0,30,50,70 \%$ 로 비율별로 첨가하였고, 반죽의 배합비는 Table 1 과 같다. 밀가루와 쌀가루의 수분함량은 각각 \%와 \%이고, 쌀가루는 밀가루에 비하여 수분흡수량이 많기 때문에 쌀가루 배합비 율이 증가하면 반죽의 수분함량도 높아진다. 저속으로 30 초, 고속으로 2 분을 믹싱하여 클린업 상태가 되면 버터를
첨가한 후, 고속으로 2 분 30 초 더 믹싱하였다. 손으로 20 회 주물러 매끈한 반죽모양을 만든 후 볼에 담고, 1 차 발효(온 도 $38^{\circ} \mathrm{C}$, 습도 $80 \%, 1$ 시간)하였다. 1 차 발효가 끝난 반죽은 $50 \mathrm{~g}$ 씩 분할하여 둥글리기를 하고, 10 분 간 벤치타임을 준 후 2 차 발효(온도 $38^{\circ} \mathrm{C}$, 습도 $80 \%, 20$ 분)를 진행하였다. 발효가 끝난 반죽은 $180^{\circ} \mathrm{C}$ 로 예열된 오븐(NSO-96, Daeyung, Seoul, Korea)에서 6분 30초씩 오븐트레이의 방향 을 바꿔가며 총 13 분 간 구웠다.

\section{혼합가루의 호화특성 측정}

강력분에 한아름 4 호와 금강 1 호 쌀가루를 첨가비율별 $(0$, $30,50,70 \%)$ 로 혼합한 가루의 페이스트 점도를 신속점도 측정기(RVA, Rapid visco analyzer, RVA-4D, Newport Scientific Inc., Narrabeen, Australia)를 사용하여 측정하였 다. 분말시료 $3.0 \mathrm{~g}$ 을 알루미늄 캔에 넣은 후 증류수 25 $\mathrm{mL}$ 을 첨가하는 것을 기준으로 하였는데, 시료의 수분함량 에 따라 첨가되는 증류수의 양이 보정되었다. 가열 및 냉각 조건은 초기온도 $25^{\circ} \mathrm{C}$ 에서 2 분 간 유지한 후 5 분 간 $95^{\circ} \mathrm{C}$ 로 가열한 다음 3 분 간 $95^{\circ} \mathrm{C}$ 로 유지하였으며, 5 분 간 $25^{\circ} \mathrm{C}$ 로 냉각하였다. 총 실험시간은 20 분이었으며 paddle의 회전은 초기 시료의 분산을 위하여 $960 \mathrm{rpm}$ 으로 회전시킨 후 160 $\mathrm{rpm}$ 에서 점도를 측정하였다(7). 페이스트 점도 곡선으로부 터 최고점도(peak viscosity), 최저점도(trough viscosity), 최 종점도(final viscosity), 강하점도(breakdown viscosity), 치 반점도(setback viscosity) 등의 페이스트 점도 지표를 각각 구하였고, 3회 측정한 값의 평균값으로 나타내었다.

\section{반죽의 $\mathrm{pH}$ 및 발효팽창력}

모닝빵 반죽의 $\mathrm{pH}$ 및 발효팽창력 측정에는 1 차 발효의 반죽을 사용하였다. 반죽의 $\mathrm{pH}$ 는 반죽 $5 \mathrm{~g}$ 과 증류수 45 $\mathrm{mL}$ 를 homogenizer로 균질화하여 여과한 후 $\mathrm{pH}$ meter (Corning 340, Mettler Toledo, Leicester, UK)를 사용하여 측정하였다. 발효팽창력 측정은 반죽 $10 \mathrm{~g}$ 을 $50 \mathrm{~mL}$ test tube에 담아 편평하게 한 후, 모닝빵 발효조건과 동일한 상태에서 15 분 간격으로 90 분 동안 발효기(EP-20, Daeyung, Seoul, Korea)에 넣고 부피변화를 기록하였다.

\section{주사전자현미경 (SEM)을 이용한 반죽의 미세구조 관찰}

2차 발효가 끝난 쌀가루 배합 비율별 반죽을 탄소 테이프 위에 고정시킨 후 scanning electron microscope(SEM; TM3000, Hitachi, Tokyo, Japan)을 이용하여 각각 5,000배, 2,000 배 확대하여 관찰하였다.

\section{반죽과 빵의 수분함량 측정}

1 차 발효가 끝난 반죽과 모닝빵의 껍질부분을 제외한 중간부분을 각각 $1 \mathrm{~g}$ 을 취한 후 $105^{\circ} \mathrm{C}$ 드라이오븐에서 overnight 시켜 수분함량을 측정하였다. 
Table 1. Formula for preparation of soft morning roll bread with different ratios of high yield tongil-type rice flours

\begin{tabular}{|c|c|c|c|c|}
\hline Ingredient $(\mathrm{g})$ & $\mathrm{W} 100+\mathrm{R} 0^{1)}$ & $\mathrm{W} 70+\mathrm{R} 30$ & W50+R50 & $\mathrm{W} 30+\mathrm{R} 70$ \\
\hline Wheat flour & 100 & 70 & 50 & 30 \\
\hline Rice flour & 0 & 30 & 50 & 70 \\
\hline Salt & 2.4 & 2.4 & 2.4 & 2.4 \\
\hline Sugar & 17 & 17 & 17 & 17 \\
\hline Water & 81 & 81 & 83 & 85 \\
\hline Defatted dry milk & 4 & 4 & 4 & 4 \\
\hline Butter & 3 & 3 & 3 & 3 \\
\hline Yeast & 2 & 2 & 2 & 2 \\
\hline Malts & 1.2 & 1.2 & 1.2 & 1.2 \\
\hline
\end{tabular}

1)Rotio was expressed as percentile, W: wheat flour, R: rice flour.

\section{빵의 외관특성 측정}

\section{외관 및 내부}

모닝빵 품질특성은 오븐에서 구운 빵을 실온에서 1시간 방냉한 후 평가하였다. 모닝빵의 단면구조는 가장 높은 부 분에서 종단으로 자른 단면을 디지털 카메라(NX 300M, Samsung, Seoul, Korea)로 촬영하여 관찰하였다.

\section{굽기 손실률, 비용적 및 높이}

모닝빵의 굽기 손실률(baking loss rate)은 모닝빵 굽기 전의 무게와 구운 후 1 시간 방냉한 무게를 측정하여 계산하 였고, 모닝빵의 비용적(specific volume)은 모닝빵의 무게와 종자치환법으로 측정된 부피를 이용하여 계산하였다(8). 높이는 모닝빵의 가장 높은 부분에서 종단으로 자른 단면을 자로 측정하였다.

\section{색 도}

모닝빵의 내부 속결의 명도( $\mathrm{L}$ 값), 적색도(a값), 황색도(b 값)는 색차계(CR-300, Minolta Co., Osaka, Japan)를 사용하 여 측정하였고, 색도 측정에 사용된 표준백판은 $\mathrm{L}$ 값 98.82 , $\mathrm{a}$ 값 $-0.1, \mathrm{~b}$ 값 -0.39 이었다.

\section{모닝빵의 조직감}

모닝빵의 조직감은 texture analyzer(TestXpert П, Zwick Roell, Ulm, UK)를 사용하여 pre-test speed $2.0 \mathrm{~mm} / \mathrm{sec}$, post-test speed $2.0 \mathrm{~mm} / \mathrm{sec}$, strain $40 \%$, probe diameter 2.5 $\mathrm{cm}$ 의 조건으로 측정하였다(9). 조직감 측정에 사용한 시료 는 가로 $(1.0 \mathrm{~cm})$, 세로 $(1.0 \mathrm{~cm})$, 높이 $(1.0 \mathrm{~cm})$ 를 일정하게 하였고, 경도(hardness), 탄력성 (springiness), 응집성 (cohesiveness), 씹힘성(chewiness)의 4가지 항목을 8회 반복 측정하였다.

\section{통계처리}

본 연구의 모든 실험 결과는 3회 이상 반복하여 평균으로
나타내었으며 SPSS software package(version 12.0, SPSS Inc., Chicago, IL, USA)를 이용하여 통계처리를 하여 다중 범위검정(Duncan's multiple range test)을 통하여 $\mathrm{p}<0.05$ 수 준에서 유의성 있는 그룹간의 차이를 검정하였고, 상관관 계는 Pearson의 상관계수로 나타내었다.

\section{결과 및 고찰}

\section{쌀가루 첨가 비율별 혼합가루의 호화특성}

쌀가루 첨가비율에 따른 호화점도 특성은 Table 2와 같 다. 최고점도(peak viscosity), 최저점도(trough viscosity), 최 종점도(final viscosity), 치반점도(setback viscosity)는 쌀가 루 첨가 비율이 증가할수록 증가하였는데, 같은 비율 쌀가 루 첨가 처리구를 비교하였을 때, 금강 1 호가 한아름4호보 다 점도가 전반적으로 더 높았다. 혼합가루의 호화는 전분 의 아밀로오스와 아밀로펙틴의 구성 비율, 전분의 구조차 이, 전분 입자의 팽윤정도, 단백질과 지방 함량 차이 등 다양한 요인에 의해 영향을 받는 것으로 알려져 있다(7). 이는 금강 1 호와 한아름4호가 아밀로스 함량이 비슷한 점을 고려했을 때, 전분의 구조나 다른 성분 구성 등의 차이에서 기인하는 것으로 생각되었다. 최고점도는 금강 1 호 $100 \%$ 가 $253.79 \mathrm{RVU}$ 로 가장 높았고, 대조구(밀가루 $100 \%$ )에서는 $122.17 \mathrm{RVU}$ 로 가장 낮았다. 노화의 경향을 나타내는 치반 점도(setback viscosity)는 대조구(밀가루100\%)에서 54.29 $\mathrm{RVU}$ 로 가장 낮아 노화가 가장 느릴 것으로 예상되었고, 한아름4호 $30 \%$ 가 $68.88 \mathrm{RVU}$, 금강 1 호 $30 \%$ 가 $76.67 \mathrm{RVU}$ 순으로 노화도가 증가할 것으로 생각되었다. 선행 연구에 서 강력분의 최고, 최저, 최종점도가 각각 $137,83,154 \mathrm{RVU}$ 이었으며 이는 본 연구결과와 유사하였다(10). 호화액의 점도 변화는 호화과정 중에 용출된 아밀로오스, 전분입자, 팽윤된 입자로부터 용출된 직선상의 고분자에 의해 기인하 는 것으로 판단하였다(7). 본 연구에서는 쌀가루를 첨가한 
Table 2. Pasting properties of blended powders with different ratios of high yield tongil-type rice flour

\begin{tabular}{cccccc}
\hline & Peak viscosity & Trough viscosity & Breakdown viscosity & Final viscosity & Setback viscosity \\
\hline W100+R0 & $122.17 \pm 1.41^{\mathrm{h} 1)}$ & $80.08 \pm 1.89^{\mathrm{g}}$ & $42.08 \pm 0.47^{\mathrm{f}}$ & $134.38 \pm 1.36^{\mathrm{h}}$ & $54.29 \pm 0.53^{\mathrm{g}}$ \\
W70+R(K1)30 & $160.04 \pm 0.65^{\mathrm{g}}$ & $99.96 \pm 1.00^{\mathrm{f}}$ & $60.08 \pm 0.35^{\mathrm{e}}$ & $176.63 \pm 0.06^{\mathrm{f}}$ & $76.67 \pm 0.94^{\mathrm{e}}$ \\
W50+R(K1)50 & $189.88 \pm 1.24^{\mathrm{e}}$ & $120.29 \pm 0.77^{\mathrm{d}}$ & $69.58 \pm 0.47^{\mathrm{d}}$ & $210.79 \pm 0.41^{\mathrm{d}}$ & $90.50 \pm 1.18^{\mathrm{c}}$ \\
W30+R(K1)70 & $233.21 \pm 3.71^{\mathrm{c}}$ & $143.00 \pm 2.95^{\mathrm{b}}$ & $82.21 \pm 2.06^{\mathrm{c}}$ & $253.00 \pm 2.59^{\mathrm{b}}$ & $110.00 \pm 0.35^{\mathrm{b}}$ \\
W0+R(K1)100 & $253.79 \pm 5.36^{\mathrm{a}}$ & $162.71 \pm 1.59^{\mathrm{a}}$ & $96.58 \pm 4.01^{\mathrm{b}}$ & $281.33 \pm 2.83^{\mathrm{a}}$ & $118.63 \pm 1.24^{\mathrm{a}}$ \\
W70+R(H4)30 & $156.25 \pm 0.00^{\mathrm{g}}$ & $97.33 \pm 2.12^{\mathrm{f}}$ & $58.92 \pm 2.12^{\mathrm{e}}$ & $166.21 \pm 0.41^{\mathrm{g}}$ & $68.88 \pm 2.53^{\mathrm{f}}$ \\
W50+R(H4)50 & $180.33 \pm 0.70^{\mathrm{f}}$ & $109.79 \pm 3.83^{\mathrm{e}}$ & $70.54 \pm 3.13^{\mathrm{d}}$ & $187.83 \pm 2.71^{\mathrm{e}}$ & $78.05 \pm 1.12^{\mathrm{e}}$ \\
W30+R(H4)70 & $209.25 \pm 0.59^{\mathrm{d}}$ & $122.63 \pm 0.06^{\mathrm{d}}$ & $86.63 \pm 0.65^{\mathrm{c}}$ & $209.83 \pm 0.24^{\mathrm{d}}$ & $87.21 \pm 0.18^{\mathrm{d}}$ \\
W0+R(H4)100 & $247.83 \pm 1.30^{\mathrm{b}}$ & $132.29 \pm 2.30^{\mathrm{c}}$ & $115.54 \pm 3.59^{\mathrm{a}}$ & $222.83 \pm 3.65^{\mathrm{c}}$ & $90.54 \pm 1.36^{\mathrm{c}}$ \\
\hline
\end{tabular}

${ }^{1)}$ Means in the same colume with different letters are significantly different $(\mathrm{p}<0.05)$. W: wheat flour, R: Rice flour, K1: Keumkang1, H4: Hanareum4.

breakdown viscosity $=\mathrm{P}-\mathrm{T}$, setback viscosity $=\mathrm{F}-\mathrm{T}$

비율이 높아질수록 혼합분의 최고점도와 최종점도가 증가 하였는데 이는 쌀가루의 첨가비율이 높을수록 전분의 비율 이 높아지기 때문으로 판단되었다. 또한, 전분은 밀가루의 호화특성, 반죽의 점탄성, 수분흡수율, 가열시의 점도 등의 변화를 가져오므로 기호성에 관련되는 성질에 영향을 주게 된다. 전분현탁액에 글루텐과 같은 단백질, pentosan, gum 질 및 당류 등을 첨가하면 호화과정에서 수분에 대해 전분 과 경쟁성을 가지므로 호화가 지연될 수 있는데(11), 쌀가루 와 달리 밀가루의 단백질 함량은 8-14\% 범위로 그 함량에 따라 제면용이나 제과, 제빵용으로 사용되며 이는 유변학 적 profile에 영향을 준다. 따라서 밀가루의 함량이 증가할수 록 단백질이 상대적으로 증가하게 되어 밀이나 쌀의 전분의 호화에 필요한 수분을 빼앗겨 현탁액의 호화온도가 증가한 것으로 사료되었다(data not shown). 밀가루에 쌀가루의 첨 가에 따른 호화양상의 변화는 제면, 제과제빵, 수프 등 밀가 루 가공제품에 쌀가루 첨가 시 고려해야 할 사항으로 판단 하였다.

\section{반죽의 $\mathrm{pH}$ 및 발효팽창력}

모닝빵 반죽의 $\mathrm{pH}$ 측정결과는 Fig. 1과 같다. 1 차 발효가 진행될수록 $\mathrm{pH}$ 는 감소하였고, 첨가한 쌀가루 함량이 증가 할수록 모닝빵 반죽의 $\mathrm{pH}$ 는 증가하는 경향이었다. 다만, $30 \%$ 와 $50 \%$ 쌀가루 첨가군은 발효 중 변화도 거의 유사하였 으며, 최종 $\mathrm{pH}$ 값도 거의 같았다. 발효 과정 중 이스트는 반죽에 함유된 당을 영양원으로 이용하여 최종적으로 $\mathrm{CO}_{2}$ 와 알코올을 생성하고 이에 따라 $\mathrm{pH}$ 는 저하되지만, 쌀가루 첨가군은 대조구에 비해 글루텐 생성력이 저하되어 $\mathrm{CO}_{2}$ 가 소실되고 또한 탄산으로의 용해도가 감소하게 되어 쌀가루 첨가 증가율에 따라 $\mathrm{pH}$ 는 높아지는 것으로 사료되었다. 발효초기 $\mathrm{pH}$ 가 한아름 4호 $70,50,30,0 \%$ 첨가군에서 각각 $6.25,6.05,5.95,5.9$ 로 나타났으며, 발효 90 분 후의 $\mathrm{pH}$ 는 각각 $6.08,5.78,5.71,5.68$ 로 발효 초기보다 약간 감소한

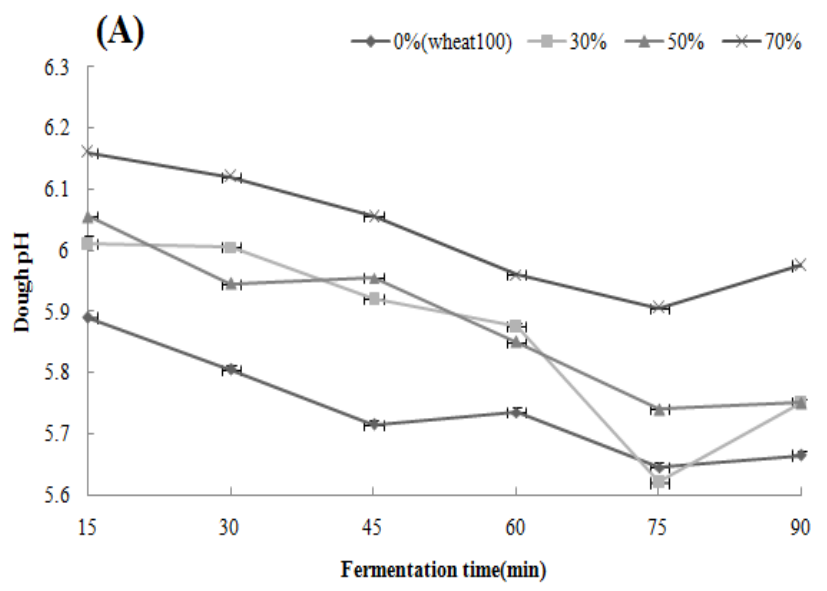

(B)

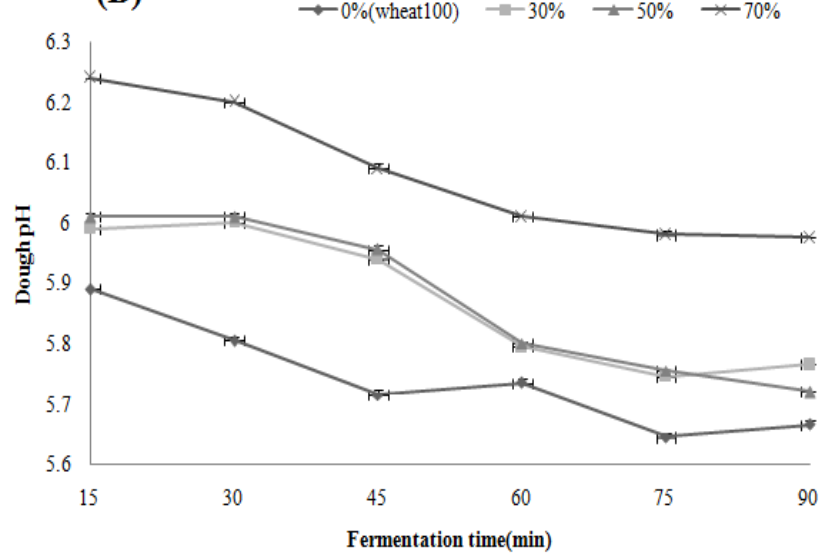

Fig. 1. $\mathrm{pH}$ change of dough with different ratios of high yield tongil-type rice flour $(\mathrm{p}<0.05)$ during fermentation. (A) Hanareum4, (B) Keumkang1.

것으로 나타났다. 금강 1 호의 경우에도, 발효초기 $\mathrm{pH}$ 가 70 , $50,30,0 \%$ 첨가군에서 각각 $6.15,6.00,6.05,5.9$ 로 나타났으 며, 발효 90 분 후의 $\mathrm{pH}$ 는 각각 $6.01,5.80,5.80,5.65$ 로 나타 나, 각 모닝빵 반죽의 $\mathrm{pH}$ 는 첨가한 쌀가루의 함량이 증가할 
수록 높아지는 경향이었다. 그러나, 쌀가루 $30 \%, 50 \%$ 첨가 처리구의 $\mathrm{pH}$ 가 품종에 관계없이 발효 시간대별로 거의 유 사한 것은 발효에 있어서 $30 \%$ 와 $50 \%$ 쌀가루 첨가가 효모의 생육 환경을 유사하게 할 수 있기 때문으로 사료되었다. Moon과 Park(12)은 반죽의 $\mathrm{pH}$ 는 빵 제조 시 효모의 발효 속도에 영향을 주는 요인이며, $\mathrm{pH}$ 는 빵에 첨가된 물의 종류, 효모 영양원의 종류, 원료의 성분에 영향을 받는다고 하였 다. 반죽의 $\mathrm{pH}$ 는 제품의 품질에 영향을 주는 요인으로 반죽 의 $\mathrm{pH} 5.0$ 이하에서는 가스 보유력이 낮아지며, $\mathrm{pH}$ 5.0-5.5 에서는 가스 보유력이 높아서 빵의 부피가 증가한다고 보고 하였다(13). 본 연구에서는 반죽의 $\mathrm{pH}$ 범위가 5.67-5.98로 나타났으며( 1 차 발효, 90 분), 쌀가루 $70 \%$ 첨가군의 반죽 $\mathrm{pH}$ 는 가장 높게 나타났는데 이는 글루텐 생성 감소에 따른 $\mathrm{CO}_{2}$ 소실 뿐만 아니라 강력분 밀가루(5.89)보다 높은 $\mathrm{pH}$ 를 가진 쌀가루(6.73)가 $70 \%$ 첨가된 결과인 것으로 생각되었 다. 찰쌀보리가루 첨가 반죽연구에서(14), 2 차 발효 후 대조 구에 비해 첨가군의 $\mathrm{pH}$ 가 유의적으로 높고, 찰쌀보리가루 첨가율이 증가할수록 반죽의 $\mathrm{pH}$ 는 증가한 결과는 쌀가루 를 첨가한 본 연구결과와도 일치하였다.

(A)

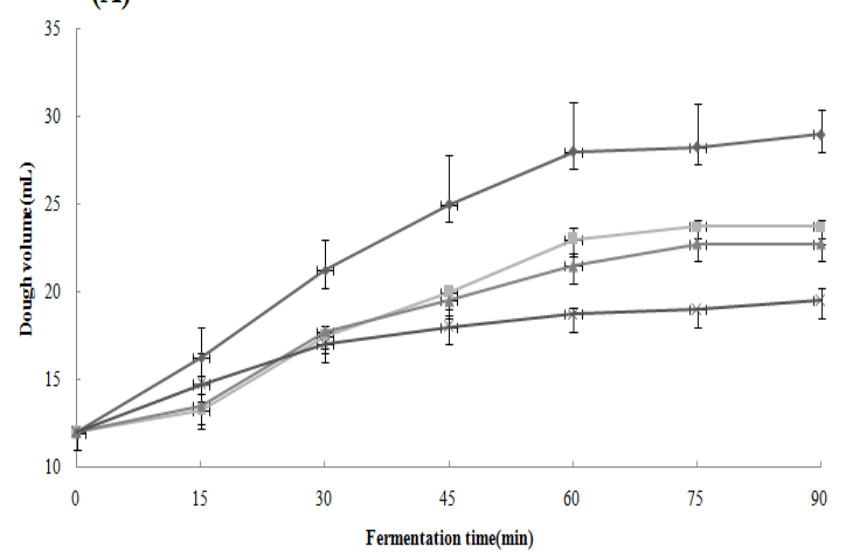

(B)

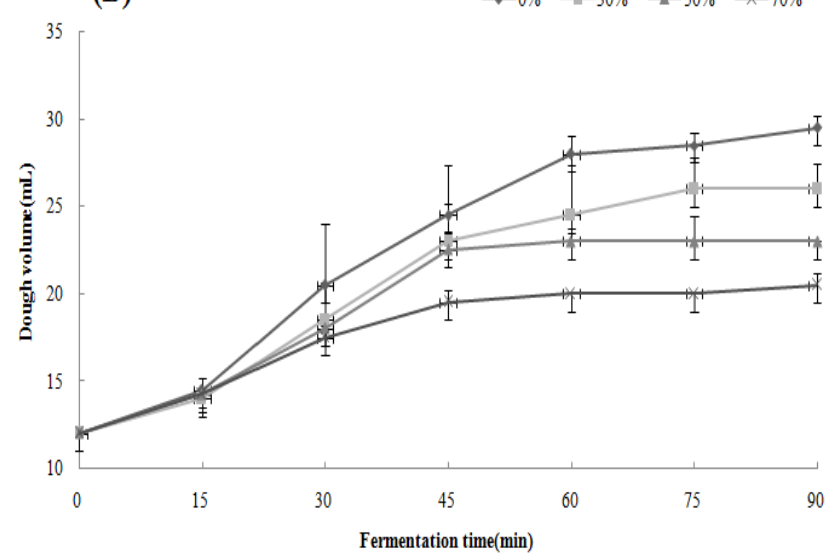

Fig. 2. Volume change of dough with different ratios of high yield tongil-type rice flour $(\mathrm{p}<0.05)$ during fermentation. (A) Hanareum4, (B) Keumkang1.
모닝빵 반죽의 발효팽창력 측정결과는 Fig. 2와 같다. 각 시료를 90 분 동안 발효시키면서 15 분 간격으로 그 부피 를 측정한 결과, 쌀가루의 첨가비율이 감소할수록 발효팽 창력은 증가하였고, 모든 시료에서 발효시간이 증가함에 따라 증가하다가 60 분 이후에는 더 이상 증가하지 않았다. 발효 30분 후부터 반죽 부피의 범위가 $18-20 \mathrm{~mL}$ 로 시료 간의 약간의 차이를 나타내었으나, 발효 60 분 후에는 시료 간에 뚜렷한 차이를 보여 품종에 관계없이 쌀가루 첨가량이 증가할수록 반죽의 부피가 감소하였다. 반죽 발효 과정에 서 이스트 영양원인 당을 공급하는 것은 밀가루에 존재하는 유리당, 이스트 또는 밀가루의 효소에 의해 분해되는 당 및 첨가 당(쌀가루로부터 기인하는 당) 등이 있으며, 이는 반죽의 발효팽창력에 영향을 줄 것으로 생각되었다. Lee (15)는 브로콜리 분말첨가량이 증가할수록 식빵 반죽의 팽 창력이 감소했다고 보고하였고, Kang과 $\mathrm{Nam}(16)$ 은 빵에 다른 첨가물을 넣어 제조할 경우 글루텐 함량과 첨가물의 성질에 따라 활성 글루텐 등의 구조를 유지할 수 있는 보조 물질을 첨가하지 않으면 구조력을 유지하기가 어려워 부피 가 감소한다고 하였다. 본 실험에서도 쌀가루의 첨가비율 이 증가할수록 발효팽창력이 감소하는 경향을 나타냈으며, 이는 모닝빵의 비용적과 높이에도 영향을 줄 것으로 사료되 었다.

\section{반죽의 SEM 구조 관찰}

쌀가루 품종 및 첨가비율별 반죽의 미세구조 관찰에서, $100 \%$ 밀가루 반죽은 구형의 직경 $15-25 \mu \mathrm{m}$ 정도의 큰 전분 입자와 2-10 $\mu \mathrm{m}$ 정도 크기의 작은 전분입자들이 반죽내부 에 형성된 protein matrix와 상호작용하면서 불규칙하게 분 포되어 있었다. 또한, 타원형의 밀 입자 사이에 발견된 작은 입자들이 관찰되었는데, 이는 본래 밀의 작은 입자 혹은 부재료일 것으로 판단되었다. 쌀 전분 입자는 다각형의 직 경 2-10 $\mu \mathrm{m}$ 의 크기를 나타내었으며, 쌀가루 함량비율이 높을수록 전분입자가 더 많이 관찰되었다(Fig. 3). SEM 사 진에서 밀가루과 쌀가루의 전분 입자가 다소 밀집되어 있는 곳이 확인되었고, 발효가 진행됨에 따라 반죽의 밀과 쌀 전분입자들이 그물망을 형성하는 것으로 나타났다. 한편, 두 가지 쌀 품종에 의한 차이는 비교적 적은 것으로 확인되 었다. Song과 Park(17)은 반죽 혼합과정에서 충분히 수화된 뒤 형성된 글루텐 단백질은 많은 수의 작은 구멍을 가진 섬유망을 형성하는데 발효 후에는 이 단백질 구조가 보다 큰 기공을 가지게 된다고 하였다. 따라서 빵 내부는 얇은 막과 큰 기공으로 채워지게 되고, 수많은 미세기공은 전분 입자들을 구조 안에 서로 얽히게 하여 기공이 커지면 기공 표면에 연결된 전분입자가 단백질을 둘러싸고 있어 단백질 구조가 면사포같이 되면서 단백질을 섬유망 안으로 펼쳐진 구조를 하게 된다고 보고하였다. 메밀가루 비율별 첨가 반 죽구조 연구(18)에서는 $100 \%$ 밀가루 반죽구조에서 큰 전분 
입자들이 선명한 형태로 분포되어 있는 것에 비하여 $10 \%$ 혼합 반죽에서 작은 구형의 전분입자들이 조밀하게 구성되 어 있었고, $30 \%$ 혼합 반죽에서는 작은 전분입자들이 더욱 더 많아져서 덩어리진 형태가 서로 혼합되어 있는 모양을 볼 수 있었는데, 이는 쌀가루를 첨가하여 반죽한 본 실험의 결과와도 유사하였다. 이러한 현상은 단백질이 $\mathrm{CO}_{2}$ 가스를 포집할 수 있는 능력을 상실하게 되고 불규칙적인 세포막이 형성되어 조밀한 빵의 내관을 형성하게 하는 원인이 된다고 하였다. Pomeranz 등(19)은 밀가루 반죽의 구조에서 큰 전 분입자들은 더욱 커지고 작은 입자들은 약간 변형되면서 protein matrix 와 결합하는 양상을 확인하였고, 이는 단백질전분 상호작용이 강화되는 것으로 발효와 더불어 미세한 그물망 구조에서 크고 탄력성 있는 것으로 변화하여 작은 빈 공간을 형성하고 있다고 하였다.

\section{모닝빵의 무게, 수분함량 및 높이, 부피, 비용적}

모닝빵의 수분함량 측정결과는 Table 3 과 같으며, 쌀가루 첨가 비율이 증가할수록 빵의 수분함량은 다소 증가하는 경향을 보였는데, 쌀가루 함량이 높은 반죽의 수분함량이 다소 높기 때문으로 사료된다. 그러나, 대조구(밀가루 $100 \%)$ 와 비교하였을 때, 통계적인 유의성은 낮은 것으로 나타났다. $100 \%$ 밀가루 빵의 수분함량은 $38.46 \%$, 금강 1 호
와 한아름 4 호의 $30,50,70 \%$ 첨가 빵은 각각 $38.91,39.41$, $40.06 \%$ 와 $38.25,39.45,38.69 \%$ 로 나타났다. $\mathrm{Kim}$ 등(20)의 par-baked 모닝빵 연구에서 현미, 보리, 귀리, 고아미 2호를 첨가한 모닝빵은 밀가루 모닝빵에 비해 수분함량이 낮았다 고 하였는데, 본 연구에서는, 밀가루 모닝빵에 비해 쌀 첨가 모닝빵의 반죽이 더 낮은 수분함량에도 불구하고 빵 수분함 량은 오히려 높게 나타난 것과는 상반되는 결과였다. 이는, 반죽 제조 후 냉동처리 하여 실험을 한 선행연구의 가공방 법 및 저장 등의 차이에서 기인하는 것으로 생각되었다. 1 차 발효 후 반죽의 수분함량은 쌀가루 $70 \%$ 첨가군에서 가장 낮았지만 쌀빵의 수분함량은 일정하지 않았는데 이는 발효기를 이용한 1 차 발효와 2 차 발효 도중 수분이 반죽내 로 흡수되어 발생한 결과로 보고된 바 있다(13). 모닝빵의 높이는 비용적의 결과와 같이 대조구가 가장 큰 부피를 나타내었고, 쌀가루 첨가량이 증가할수록 부피가 감소하였 으며, 글루텐 양의 부족에 따라 빵의 기본구조 형성이 제대 로 이루어지지 않은 것으로 판단되었다(Table 3).

쌀가루 30-50\% 첨가군에서 금강1호 쌀가루의 모닝빵이 한아름4호보다 더 잘 부푸는 것으로 나타났다. 대조구인 밀가루 모닝빵의 높이 $58.19 \mathrm{~mm}$ 대비, 금강 1 호와 한아름 4 호 $30 \%$ 첨가군의 모닝빵 높이는 각각 $55.95,54.10 \mathrm{~mm}$ 를, $50 \%$ 에서는 각각 $45.95,42.06$ 을 나타내었다. 빵 부피는 대

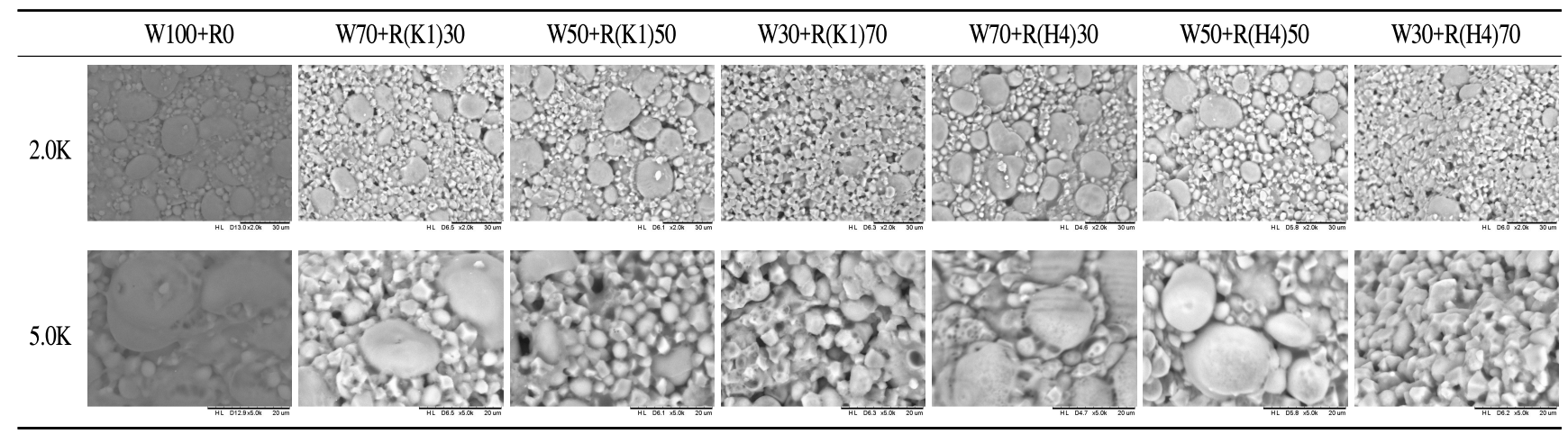

Fig. 3. Scanning electron micrographic images of dough with different ratios of high yield tongil-type rice flours.

Table 3. Quality characteristics of dough and soft morning roll bread with different ratios of high yield tongil-type rice flour

\begin{tabular}{ccccccc}
\hline & $\begin{array}{c}\text { Dough moisture } \\
(\%)\end{array}$ & $\begin{array}{c}\text { Bread weight } \\
(\mathrm{g})\end{array}$ & $\begin{array}{c}\text { Rice bread moisture } \\
(\%)\end{array}$ & $\begin{array}{c}\text { Bread height } \\
(\mathrm{cm})\end{array}$ & $\begin{array}{c}\text { Bread loaf volume } \\
(\mathrm{mL})\end{array}$ & $\begin{array}{c}\text { Specific volume } \\
(\mathrm{mL} / \mathrm{g})\end{array}$ \\
\hline W100+R0 & $60.66^{\mathrm{a})}$ & $44.40^{\mathrm{b}}$ & $38.46^{\mathrm{c}}$ & $58.19^{\mathrm{a}}$ & $192.50^{\mathrm{a}}$ & 4.34 \\
W70+R(K1)30 & $60.01^{\mathrm{a}}$ & $43.87^{\mathrm{c}}$ & $38.91^{\mathrm{bc}}$ & $55.95^{\mathrm{b}}$ & $162.50^{\mathrm{b}}$ & 3.70 \\
W50+R(K1)50 & $60.22^{\mathrm{ab}}$ & $44.80 \mathrm{a}$ & $39.41^{\mathrm{ab}}$ & $45.95^{\mathrm{d}}$ & $127.50^{\mathrm{c}}$ & 2.85 \\
W30+R(K1)70 & $59.29^{\mathrm{c}}$ & $43.91^{\mathrm{c}}$ & $40.06^{\mathrm{a}}$ & $31.88^{\mathrm{g}}$ & $100.00^{\mathrm{c}}$ & 2.28 \\
W70+R(H4)30 & $60.10^{\mathrm{ab}}$ & $44.26^{\mathrm{b}}$ & $38.25^{\mathrm{c}}$ & $54.10^{\mathrm{c}}$ & $160.00^{\mathrm{b}}$ & 3.62 \\
W50+R(H4)50 & $59.95^{\mathrm{abc}}$ & $44.25^{\mathrm{b}}$ & $39.45^{\mathrm{ab}}$ & $42.06^{\mathrm{b}}$ & $110.00^{\mathrm{d}}$ & 2.49 \\
W30+R(H4)70 & $59.67^{\mathrm{bc}}$ & $43.18^{\mathrm{d}}$ & $38.69^{\mathrm{bc}}$ & $34.49^{\mathrm{f}}$ & $90.00^{\mathrm{f}}$ & 2.08 \\
\hline
\end{tabular}

${ }^{11}$ Means in the same colume with different letters are significantly different $(\mathrm{p}<0.05)$.

W: wheat flour, R: Rice flour, K1: Keumkang1, H4: Hanareum4. 
조구(밀가루 $100 \%$ )가 $192.5 \mathrm{~mL}$ 로 가장 컸고, 금강1호와 한아름4호 $30 \%$ 첨가군에서는 $162.5,160.0 \mathrm{~mL}$ 를, $50 \%$ 첨가 군에서는 각각 $127.5,110.0 \mathrm{~mL}$ 을 나타내었다. 모닝빵의 높이와 부피는 밀가루 첨가량이 많을수록 증가하였고, 품 종 간 비교에서는 금강 1 호가 한아름4호보다 더 우수하였 다. 쌀가루 $70 \%$ 첨가군은 빵의 구조물인 형태를 유지하는 데 절대적인 글루텐이 부족하여 빵으로서 품질이 매우 낮았 다. 비용적(specific volume)에서는 대조구(밀가루 100\%)가 $4.34 \mathrm{~mL} / \mathrm{g}$ 로 가장 높았고, 금강 1 호 $30 \%$ 첨가군 $3.7 \mathrm{~mL} / \mathrm{g}$, 한아름 4 호 $30 \%$ 첨가군 $3.62 \mathrm{~mL} / \mathrm{g}$ 순이었으며, 첨가 쌀가루 함량이 늘어날수록 비용적은 감소하였고, 품종 간 비교에 서는 금강 1 호가 한아름4호보다 높았다.

\section{모닝빵의 단면과 색도}

모닝빵의 단면을 관찰한 결과, 금강 1 호로 만든 모닝빵이 한아름 4호보다 더 컸고, 쌀가루 첨가 비율이 늘어날수록 빵의 크기가 작아졌다(Fig. 4). 빵의 기공 관찰 결과, 대조구 (밀가루 $100 \%$ )에서 가장 작고 균일한 형태를 보였다. 쌀가 루 첨가량이 늘어날수록 기공 조밀도가 높았는데, 이는 굽 는 과정에서 곡류가루가 무거워 빵이 팽창하지 못하고 수분 이 밖으로 유출되어 빵 반죽이 가라앉아 조밀해진 것으로 보고되었다(19). 또한, 흑미 첨가 쌀 식빵 연구(21)에서 현미 가루 첨가량이 적을수록 좀 더 균일하고 작은 형태의 기공 을 나타냈고, 첨가량이 많을수록 매우 조밀한 기공 상태를 보여주었다고 보고하였다. 모닝빵의 색도 측정 결과는 Table 4 와 같다. 쌀가루 첨가 비율이 증가함에 따라 금강 1 호 $50 \%$ 처리구를 제외하고는, 모닝빵의 $\mathrm{L}$ 값이 감소하였고, $\mathrm{a}$ 값과 $\mathrm{b}$ 값은 유의적으로 증가하였다. L값의 경우, $30 \%$ 처리
구에서 금강 1 호와 한아름 4 호 모두 밀가루 $100 \%$ 모닝빵의 명도값과 유의적으로 차이가 나지 않았으나, $\mathrm{a}$ 값과 $\mathrm{b}$ 값에 서는 밀가루 $100 \%$ 의 $0.29,17.88$ 대비 금강 1 호와 한아름 4 호 각각 $-0.36,17.27$ 과 $-0.06,16.58$ 을 나타내어 $\mathrm{a}$ 값과 $\mathrm{b}$ 값이 쌀가루 첨가에 따라 다소 감소하는 것을 확인하였다. 또한 $\mathrm{a}$ 값은 첨가 쌀가루 비율이 높아질수록 증가하는 경향을 보였고, 금강1호보다 한아름4호 첨가 모닝빵에서 더 높았 는데, Kim 등(14)은 식빵의 색도 변화가 첨가한 시료와 매우 밀접한 관계가 있다고 보고하였다. 빵의 외부 색도는 아미 노산 화합물과 환원당과의 반응에 의해 형성되는 효소적 갈변반응인 마이야르 반응(mailard reaction)과 당류가 일으 키는 산화반응 등에 의해 생성되는 비효소적 갈변반응인 캐러멜화(caramelization)에 기인한다. 이는 고소함과 진한 색의 원인이 되는 중요현상 중 하나로 $100 \%$ 밀가루로 만든 모닝빵에서는 충분하게 마이야르 반응이 일어날 수 있는 아미노산의 절대량으로 인해 표면 색상이 짙은 갈색으로 갈변반응이 잘 일어났다. 대조적으로, 쌀가루 첨가비율이 늘어날수록 표면이 하얗게 되었는데, 이는 아미노산의 절 대량의 부족에서 마이야르 반응이 제대로 일어나지 못하기 때문에 발생하는 현상이라 사료되었다. 대조구의 명도, 적 색도, 황색도 값이 가장 높게 나타났으며, 쌀가루의 첨가량 이 증가할수록 대체적으로 감소하는 경향을 나타내었다. 또한, 금강 1 호의 쌀모닝빵이 한아름4호 모닝빵보다 팽창도 가 우수하였는데, 한아름 4호로 만든 빵이 옆으로 퍼지는 형태를 보이는 것에 비해 금강1호로 만든 빵은 위로 볼록한 형태를 유지하였다. 이러한 특성들이 다른 제빵 품질 지표 에도 영향을 줄 수 있을 것이라 생각되었다.
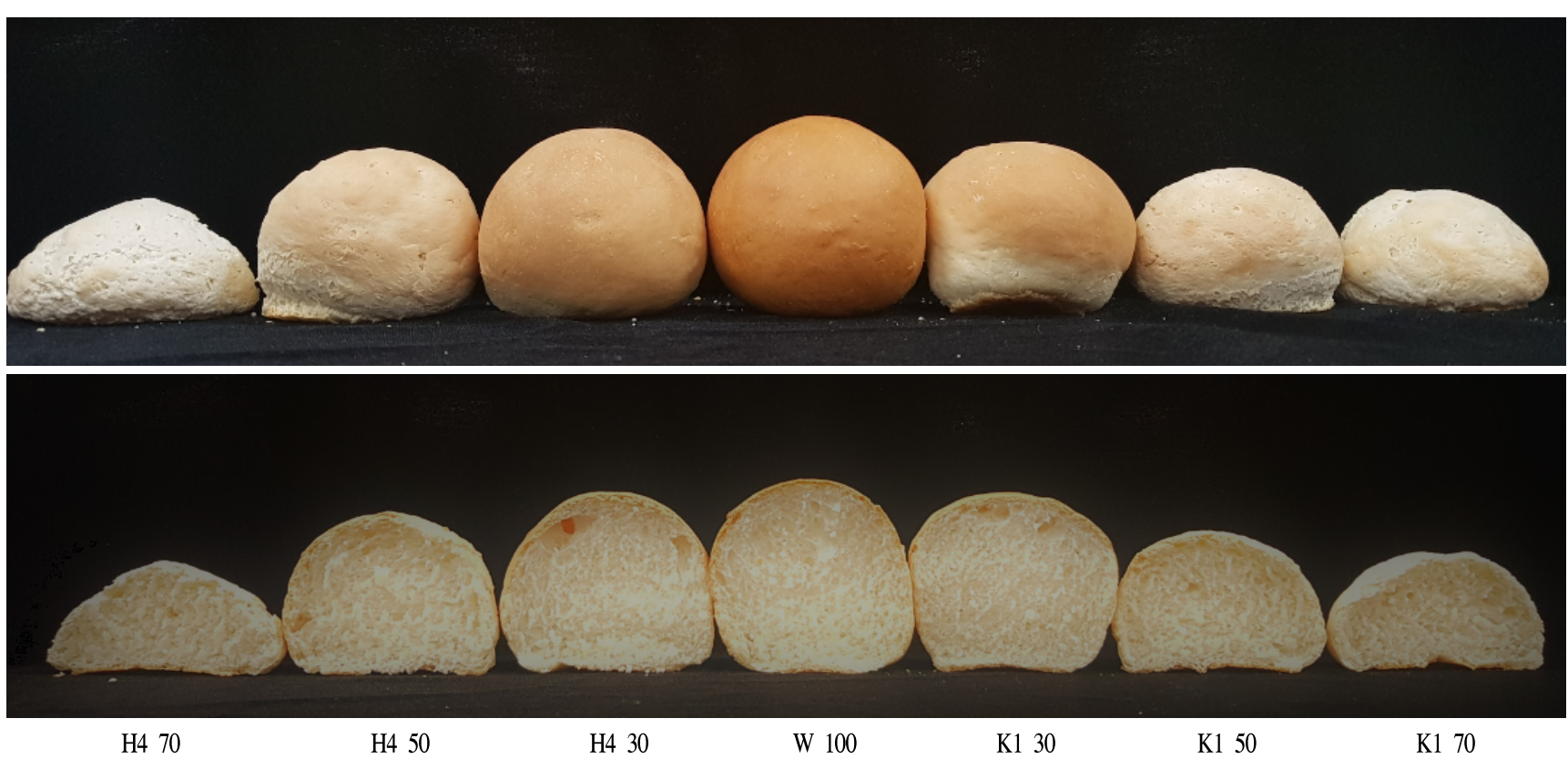

Fig. 4. Interior and exterior appearance of soft morning roll bread with different ratios of high yield tongil-type rice flours. 


\section{모닝빵의 조직감}

모닝빵의 조직감을 측정한 결과는 Table 4와 같다. 모닝 빵의 경도는 품종에 관계없이 $70 \%$ 쌀가루 첨가군에서 $411.13,435.38 \mathrm{~g}$ 으로 가장 높았고, 쌀가루 비율이 감소할수 록 경도는 낮아졌다. 대조구(밀가루 $100 \%$ )의 모닝빵 경도 는 $75.63 \mathrm{~g}$ 으로 가장 낮았으나 금강 1 호 $30 \%$ 첨가군의 경도 는 $88.50 \mathrm{~g}$ 으로 대조구와 통계적으로 유의한 차이가 나지 않았다. 탄성 및 응집성은 대조구가 각각 0.78 과 0.64 로 가장 높았고, 금강 1 호와 한아름4호 $30 \%$ 첨가군에서는 각각 $0.72,0.56$ 와 $0.71,0.55$ 로 그 뒤를 이었다. 씹힘성 측정 결과, 쌀가루 첨가비율이 증가할수록 품종에 관계없이 증가하는 경향을 보였는데 이는 경도와 유사한 경향이었다. 선행연 구에서 쌀 식빵에 흑미가루를 첨가할수록 경도가 높아진다 고 하였고(21), 모닝빵에 현미가루를 첨가하면 대조구에 비해 경도, 검성 및 씹힘성이 높아진다고 보고하였는데(20) 백미가루를 첨가한 본 연구결과와도 일치하였다. 대조구 (밀가루 $100 \%$ )와 금강1호 및 한아름4호 $30 \%$ 첨가군의 씹힘 성은 가장 낮은 값을 나타내었으며, 처리구 간 통계적으로 유의한 차이는 없었다. 특히, 탄성과 응집성을 제외한 물성 측정에서, 금강 1 호 $30 \%$ 첨가군은 밀가루 $100 \%$ 빵과 유사 한 특성을 보였으며, 통계적으로 유의한 차이가 없었다. 관능특성에서는, 밀가루 $100 \%$ 모닝빵이 원료 밀가루의 고 유 특성인 탄성으로 인한 쫄깃한 질감을 나타내었고, 쌀가 루 첨가 모닝빵은 밀가루 $100 \%$ 모닝빵보다 찐득한 질감을 나타냈다. $30 \%$ 쌀가루 첨가군이 품종에 관계없이 가장 우 수하였고, 첨가 쌀 비율이 $50,70 \%$ 으로 늘어날수록 낮은 기호도를 나타내었다. 흑미 쌀가루를 연질미와 배합한 쌀 식빵 연구에서 흑미 쌀가루를 $40 \%$ 이상 첨가한 식빵은 쓴맛이 느껴져, 맛의 선호도가 낮아졌으며, 흑미 쌀가루 첨가량이 증가할수록 외형에 대한 선호도는 낮아졌다고 보고되었다(22).

\section{요 약}

본 연구는 다수성 벼 품종인 금강 1 호와 한아름 4 호 건식 쌀가루를 제조하여, 품종별 쌀가루 첨가비율별 모닝빵 품 질 특성에 미치는 영향을 살펴보았다. 품질특성으로는 반 죽의 $\mathrm{pH}$ 및 발효팽창력, 단면관찰(SEM), 모닝빵의 수분함 량, 비용적, 높이, 색도, 물성 등을 평가하였다. 쌀가루 및 밀가루 원료의 호화점도(최고, 최저, 강하, 최종, 치반) 평가 에서 밀가루가 쌀가루 점도보다 낮았으며, 쌀가루 첨가량 이 증가할수록 호화점도는 증가하였다. 금강 1 호의 점도가 한아름4호보다 강하점도(BV)를 제외한 나머지 항목에서 모두 높았다. 반죽의 $\mathrm{pH}$ 는 쌀가루의 첨가량이 증가할수록 높아졌으며, 발효시간이 증가함에 따라 감소하였는데, 쌀 가루 $30 \%$ 와 $50 \%$ 첨가군의 반죽에서 $\mathrm{pH}$ 경향이 유사하게 나타났다. 반죽 팽창률에서는 품종에 관계없이 발효 60 분 부터 부피가 거의 변하지 않았고, 쌀가루 함량이 증가할수 록 부피가 감소하였다. 한편, 쌀가루의 첨가량이 많아질수 록 반죽에 필요한 가수량 및 모닝빵의 경도와 씹힘성은 증가하였고, 모닝빵 속결의 백색도 및 황색도는 높아지는 경향이었다. 빵 단면의 육안 관찰에서는 금강 1 호 $30 \%$ 처리 구의 오븐스프링이 크게 일어났으나, $100 \%$ 밀가루 빵에 비해 지지력이 약해서 빵의 윗부분이 내려앉는 모양을 보였 고, 기공은 비교적 일정하였다. 관능특성에서는 $30 \%$ 쌀가 루 첨가군이 가장 우수하였고, 쌀가루 비율이 $50 \%, 70 \%$ 로 늘어날수록 낮은 기호도를 나타내었다. 이번 연구결과로부 터, 다수확 품종인 금강 1 호의 건식쌀가루를 밀가루 대비 $30 \%$ 대체할 경우 대조구인 $100 \%$ 밀가루 모닝빵과 비교 시, 유사한 품질특성을 나타내는 것을 확인하였다.

Table 4. TPA properties and Hunter's color value of soft morning roll bread with different ratios of high yield tongil-type rice flour

\begin{tabular}{cccccccc}
\hline & Hardness $(\mathrm{g})$ & Springiness & Cohesiveness & Chewiness & \multicolumn{3}{c}{ Color value } \\
\cline { 6 - 8 } & & & & $\mathrm{L}$ & \multicolumn{2}{c}{$\mathrm{a}$} & $\mathrm{b}$ \\
\hline $\mathrm{W} 100+\mathrm{R} 0$ & $75.63^{\mathrm{el})}$ & $0.78^{\mathrm{a}}$ & $0.64^{\mathrm{a}}$ & $37.61^{\mathrm{d}}$ & $82.37 \pm 0.24^{\mathrm{a}}$ & $0.29 \pm 0.03^{\mathrm{a}}$ & $17.88 \pm 0.11^{\mathrm{ab}}$ \\
W70+R(K1)30 & $88.50^{\mathrm{de}}$ & $0.72^{\mathrm{b}}$ & $0.56^{\mathrm{b}}$ & $34.98^{\mathrm{d}}$ & $82.34 \pm 0.21^{\mathrm{a}}$ & $-0.36 \pm 0.05^{\mathrm{d}}$ & $17.27 \pm 0.21^{\mathrm{b}}$ \\
W50+R(K1)50 & $201.38^{\mathrm{c}}$ & $0.68^{\mathrm{c}}$ & $0.54^{\mathrm{b}}$ & $73.10^{\mathrm{c}}$ & $78.03 \pm 0.49^{\mathrm{c}}$ & $-0.60 \pm 0.04^{\mathrm{e}}$ & $16.23 \pm 0.12^{\mathrm{c}}$ \\
W30+R(K1)70 & $411.13^{\mathrm{a}}$ & $0.55^{\mathrm{e}}$ & $0.44^{\mathrm{d}}$ & $98.86^{\mathrm{b}}$ & $80.22 \pm 0.35^{\mathrm{b}}$ & $0.11 \pm 0.06^{\mathrm{b}}$ & $17.74 \pm 0.94^{\mathrm{ab}}$ \\
W70+R(H4)30 & $113.88^{\mathrm{d}}$ & $0.71^{\mathrm{b}}$ & $0.55^{\mathrm{b}}$ & $44.62^{\mathrm{d}}$ & $82.39 \pm 0.50^{\mathrm{a}}$ & $-0.06 \pm 0.02^{\mathrm{c}}$ & $16.58 \pm 0.67^{\mathrm{c}}$ \\
W50+R(H4)50 & $229.38^{\mathrm{b}}$ & $0.66^{\mathrm{cd}}$ & $0.51^{\mathrm{c}}$ & $77.38^{\mathrm{c}}$ & $79.39 \pm 0.14^{\mathrm{b}}$ & $0.20 \pm 0.02^{\mathrm{ab}}$ & $18.40 \pm 0.16^{\mathrm{a}}$ \\
W30+R(H4)70 & $435.38^{\mathrm{a}}$ & $0.63^{\mathrm{d}}$ & $0.49^{\mathrm{c}}$ & $134.90^{\mathrm{a}}$ & $77.72 \pm 2.05^{\mathrm{c}}$ & $0.21 \pm 0.16^{\mathrm{ab}}$ & $18.34 \pm 0.15^{\mathrm{a}}$ \\
\hline
\end{tabular}

${ }^{1)}$ Means in the same colume with different letters are significantly different $(\mathrm{p}<0.05)$.

W: wheat flour, R: Rice flour, K1: Keumkang1, H4: Hanareum4. 


\section{감사의 글}

본 연구는 농촌진흥청 연구사업(과제번호: PJ01026703) 의 지원에 의해 이루어진 것이며 이에 감사드립니다.

\section{References}

1. Korea Agro-Fisheries \& Food Trade Corporation (2018) Processed food segment market status, bread. Food Information Statistics System 11-1543000-002285-01

2. The Korea Rice Foodstuffs Association. http://www.krfa.or.kr/customer/faqList.do.(access August 2018)

3. Lee MH, Lee YT (2006) Bread-making properties of rice flours produced by dry, wet and semi-wet milling. J Korean Soc Food Sci Nutr, 35, 886-890

4. Kang MY, Han JY (2000) Comparison of some characteristics relevant to rice bread made from eight varieties of endosperm mutants between dry and wet milling process. Korean J Food Sci Technol, 32, 75-81

5. Ju HW, Lee KS (2016) Quality characteristics of white pan bread with Haenaru rice flour. Korean J Culin Res, 22, 44-56

6. Yook HS, Kim YH, Ahn HJ, Kim DH, Kim JO, Byun MW (2000) Rheological properties of wheat flour dough and qualities of bread prepared with dietary fiber purified from ascidian(Halocynthia roretzi) tunic. Korean J Food Sci Technol, 32, 387-395

7. Sim EY, Lee JY, Cho JH, Yoon MR, Kwak JE, Kim NG, Jeon YH, Lee CK, Lee JS, Hong HC (2018) Quality characteristics of porridge made from different Korean rice varieties including high yield tongil-type rice. Korean J Food Preserv, 25, 651-658

8. Ronald HZ (1993) Bread lecture book. American Institue of Baking, Kansas City, MO, USA, p 1311

9. Kadan RS, Robinson MG, Thibodeaux DP, Pepperman AB (2001) Texture and other physicochemical properties of whole rice bread. J Food Sci, 66, 940-944

10. Lee HM, Lee YT (2013) Pasting properties of corn, potato, sweet popato starches and wheat flours with partial rice starch substitution. Food Eng Prog, 17, 238-244
11. Pomeranz Y (1985) Carbohydrate: starch In Functional Properties of Food Component. Academic Press, New York, USA, p 64

12. Moon SW, Park SH (2008) Quality characteristics of white pan bread with chungkukjang powder. J Korean Soc Food Sci Nutr, 37, 633-639

13. Kim YS, Chun SS, Jung ST, Kim RY (2002) Effects of lotus root powder on the quality of dough. Korean J Soc Food Cook Sci, 18, 573-578

14. Kim YS, Park JY, Lee JH (2014) Quality characteristics of bread dough added with immature chalssalbori flour. Korean J Food Cook Sci, 30, 385-393

15. Lee SH (2015) Quality and antioxidant properties of white breads enhanced with broccoli(Brassica oleracea L.) powder. Korean J Food Cook Sci, 31, 614-622

16. Kang MY, Nam YJ (1999) Studies on bread-making quality of colored rice (Suwon415) flours. Korean J Soc Food Sci, 15, 37-41

17. Song JC, Park HC (1995) Food rheology. Ulsan university publishing department, Ulsan, Korea, $p$ 561-570

18. Kwon HR, Ahn MS (1995) A study on rheological and general baking properties of breads and their rusks prepared of various cereal flours. Korean J Soc Food Sci, 11, 479-486

19. Pomeranz Y, Mayer D, Seibel W (1984) Wheat, wheat-rye, and rye dough and bread studied by scanning electron microscopy. Cereal Chem, 61, 53-59

20. Kim HA, Song CR, Kim YS (2014) The quality characteristics of par-baked morning buns made with cereals powder. Korean J Culin Res, 20, 102-114

21. Im JS, Lee YT (2010) Quality characteristics of rice bread substituted with black rice flour. J East Asian Soc Dietary Life, 20, 903-908

22. Choi OJ, Jung HN, Shin SH, Kim YD, Shim JH, Shim KH (2015) Quality characteristics of gluten-free rice bread formulated with soft-type rice flour mixed with black-rice flour. Korean J Community Living Sci, 26, $447-456$ 